\title{
Slametan sebagai Simbol Harmoni dalam Interaksi Sosial Agama dan Budaya Masyarakat Desa Tanon Kecamatan Papar Kabupaten Kediri
}

\author{
Umi Hanik, ${ }^{1}$ Moh. Trumudi ${ }^{2}$ \\ ${ }^{1}$ Institut Agama Islam Negeri Kediri, ${ }^{2}$ Institut Agama Islam Tribakti Kediri \\ Iumi.hanikkdr@gmail.com, ${ }^{2}$ moh.turmudi58@gmail.com
}

\begin{abstract}
This article was written with the aim to describe the interaction of religion and culture that occurred in the people of Tanon Village, Papar District, Kediri Regency, East Java. The issue of tolerance between religious communities will always be interesting to discuss, this is because religion is often a source of conflict. A pluralist and inclusive attitude becomes the social capital of the people to live in harmony. This study uses a qualitative method with a phenomenological approach. In-depth interviews became the main technique in collecting data and then analyzed using the Haberman and Milles flow techniques. The results showed that the social interactions developed by the Tanon villagers were able to create harmony in the life between religious communities
\end{abstract}

Keywords: Slametan, Simbol Harmoni, Interaksi Sosial, Agama dan Budaya, Masyarakat Desa Tanon

\begin{abstract}
Abstrak
Artikel ini ditulis dengan tujuan untuk medeskripsikan interaksi agama dan budaya yang terjadi pada masyarakat Desa Tanon Kecamatan Papar Kabupaten Kediri Jawa Timur. Isu toleransi antar umat beragama akan selalu menarik untuk dibahas, hal ini dikarenakan agama seringkali mejadi sumber konflik. Sikap pluralis dan inklusif menjadi modal sosial masyarakat untuk hidup harmoni. Penelitian ini menggunakan metode kualitatif dengan pendekatan fonomenologi. Wawancara mendalam menjadi tiknik utama dalam mengumpulkan data dan kemudian dianalisis menggunakan teknik alir Haberman dan Milles. Hasil penelitian menunjukan bahwa interaksi sosial yang dibangun oleh masyarakat desa Tanon mampu menciptakan harmoni dalam kehidupan antar umat beragama.
\end{abstract}

Kata Kunci: Slametan, Simbol Harmoni, Interaksi Sosial, Agama dan Budaya, Masyarakat Desa Tanon

\section{Pendahuluan}

Keberagaman dan perbedaan merupakan realitas yang tidak dapat dihindari dalam kehidupan masyarakat. Realitas ini dapat menjadi potensi untuk terjadinya konflik antar agama jika tidak dilandasi oleh sikap pluralis dan inklusif oleh semua warga masyarakat yang beragam. Namun jika keberagaman dapat dikelola dengan baik oleh semua warga 
masyarakat, keberagaman dan perbedaan tersebut dapat menjadi entitas baru yang dapat dijadikan sebagai alat integrasi masyarakat. Slametan yang dilaksanakan oleh masyarakat desa Tanon ini merupakan simbol yang dijadikan alat integrasi keberagaman.

Umat beragama di desa Tanon memiliki lokal genius, yakni memiliki agama, akan tetapi masih ada kepercayaan yang diyakini dan memiliki pengaruh di masyarakat. Selain hal tersebut, juga percaya bahwa benda-benda mempunyai kekuatan gaib. Perpaduan antara animisme, mistik dan agama, mistik dan agama disebut senkritisme. Kegiatan semacam ini terlihat pada acara: slametan, ${ }^{1}$ kelahiran, ${ }^{2}$ khitanan, pernikahan, kematian, mendirikan rumah, mulai menanam padi, panen padi, kepercayaan kepada hitungan hari Pon, Kliwon, Wage, Legi, Pahing dan sebagainya.

Ritual slametan ada di semua agama, Islam, Hindu, Katolik dan Kristen, ini adalah bukti salah satu simbol keharmonisan, ${ }^{3}$ bahwa mereka sama-sama memiliki keyakinan yang sama, bukan beda, sehingga agama yang berbeda bukan merupakan sekat atau jarak sosial bagi umat beragama di desa Tanon, dan masih banyak ritual lain, yang menjadi keyakinan umat beragama di desa Tanon. Para elit agama di desa Tanon mengutamakan keharmonisan, dalam aspek yang berhubungan antar umat beragama, dalam bentuk kebersamaan dan gotong-royong, dalam kehidupan sehari-hari. Keharmonisan yang terjadi selama ini di desa Tanon, telah dijaga dan dilestarikan oleh para elit agama, ${ }^{4}$ meskipun dengan mengorbankan hak-hak individu.

Sebagaimana sudah menjadi wacana yang sangat familiar dalam dunia akademik, Geertz menulis sebuah buku yang amat menggemparkan jagat akademik Indonesia: The Religion of Java. Dalam buku yang diterjemahkan dalam bahasa Indonesia menjadi agama masyarakat Jawa ini, memaparkan tipologi atau kategori agama masyarakat Jawa, melalui tiga varian yang disebutnya: Abangan, Santri dan Priyayi. Menurut Gerrtz, tiga varian keberagaman masyarakat Jawa diambil dari istilah yang digunakan oleh orang Jawa sendiri, ketika mendefinisikan kategori keagamaan mereka. ${ }^{5}$

\footnotetext{
1 A. Kholil, “Agama Dan Ritual Slametan: Deskripsi-Antropologis Keberagamaan Masyarakat Jawa,” El-HARAKAH (TERAKREDITASI) 1, no. 1 (April 30, 2009), https://doi.org/10.18860/el.v1i1.424; Universitas Negeri Jakarta and Ahmad Hakam, "Communal Feast Slametan: ",Belief System, Ritual, and the Ideal of Javanese Society Hayula: Indonesian Journal of Multidisciplinary Islamic Studies 1, no. 1 (January 31, 2017): 97-111, https://doi.org/10.21009/hayula.001.1.06.

${ }^{2}$ Magister Arsitektur Lingkungan Binaan, Universitas Brawijaya et al., "Ruang Budaya Pada Proses Daur Hidup (Kelahiran) Di Dusun Wedoro Gresik," Review of Urbanism and Architectural Studies 13, no. 1 (June 1, 2015): 26-35, https://doi.org/10.21776/ub.ruas.2015.013.01.3.

${ }^{3}$ Rini Fidiyani, "Kerukunan Umat Beragama Di Indonesia (Belajar Keharomonisan Dan Toleransi Umat Beragama Di Desa Cikakak, Kec. Wangon, Kab. Banyumas)," Jurnal Dinamika Hukum 13, no. 3 (September 2013): 468-482, https://doi.org/10.20884/1.jdh.2013.13.3.256.

${ }^{4}$ Nazmudin Nazmudin, "Kerukunan Dan Toleransi Antar Umat Beragama Dalam Membangun Keutuhan Negara Kesatuan Republik Indonesia (NKRI)," Journal of Government and Civil Society 1, no. 1 (February 22, 2018): 23, https://doi.org/10.31000/jgcs.v1i1.268. 1996).

${ }^{5}$ Clifford Geertz, The Religion of Java, Nachdr., Anthropology/Comparative Religions (Chicago: Univ. of Chicago Press,
} 


\section{Metode}

Penelitian ini menggunakan metode penelitian kualitatif dengan pendekatan fenomenelogi. Penedekatan fenomenologi ${ }^{6}$ digunakan untuk mencari makna tradisi slametan yang dilakukan oleh masyarakat beragama di Desa Tanon Kecamatan Papar Kabupaten Kediri yang memiliki karakteristik beragam agama yang dianutnya. Informan dalam penelitian ini adalah tokoh agama dari seluruh agama yang dianut oleh masyarakat Desa Tanon yang berjumlah 5 orang dan ditambah 2 orang dari perangkat desa dan 5 orang dari masing-masing pemeluk agama.

Teknik pengumpulan data yang digunakan adalah wawancara mendalam kepada setiap informan. Teknik ini digunakan karena sifat pendekatan fenomenologi yang ingin mendeskripsikan makna peristiwa slametan sebagai simbol harmoni antar agama perspektif masyarakat desa tanon. Poses analisis data menggunakan teknik alir dari Haberman dan Milles dengan menggunakan teori interaksionisme simbolik sebagai pisau analisisnya.

\section{Temuan dan Pembahasan}

\section{Interaksi sosial dalam Perspektif Penganut Islam}

Dalam berinteraksi, umat Islam di Desa Tanon menunjukkan bahwa betul-betul mengamalkan ajaran Islam ini, terbukti dengan adanya suasana keakraban ketika bertemu di jalan, sawah, pengajian pada suasana jama'ah shalat lima waktu mereka sangat bersahabat, terlebih dari ungkapan wajah ketika berpandangan dan bersalaman satu sama yang lain, berbincang-bincang membahas apa saja yang terlintas di pikiran mereka dengan saling mengenal dan akrab ini, menciptakan suasana kebersamaan dan kerukunan.

Masyarakat Islam di desa Tanon juga saling tolong-menolong di antara mereka, terbukti ketika dalam peristiwa kelahiran, pernikahan dan kematian atau dalam suasana lain yang membutuhkan bantuan mereka seolah satu badan ketika anggota lain merasa sakit maka semua ikut merasakan, sehingga timbul suasana saling tolong-menolong.

Dalam melaksanakan dan mengamalkan ajaran tentang berlomba dalam kebaikan masyarakat Tanon mengaplikasikan pada pelaksanaan penyemarakan da'wah Islamiyah, melalui takbir keliling yang suasana ini bermuatan menguatkan eksistensi Islam di desa Tanon, juga adanya lomba musholla dan masjid paripurna yang sudah membudaya, selain jam'iyah yasin, tahlil, dhibaiyah dan kajian-kajian keislaman, suasana saling berbahas

${ }^{6}$ Heddy Shri Ahimsa-Putra, "Fenomenologi Agama: Pendekatan Fenomenologi Untuk Memahami Agama," Walisongo: Jurnal Penelitian Sosial Keagamaan 20, no. 2 (December 2012): 271-304, https://doi.org/10.21580/ws.20.2.200.

Tribakti: Jurnal Pemikiran Keislaman

Volume 31, Nomor 1, Januari 2020 
kebaikan, beramal sholeh antar umat Islam. Islam tidak membeda-bedakan yang kaya, miskin, pangkat dan simbol stratifikasi yang lain, namun dalam Islam dijelaskan, yang paling mulia dihadapan Allah SWT adalah yang paling bertaqwa.” (QS.Al Hujorot 13). Hal di atas merupakan stratifikasi secara vertikal. Dalam sisi lain juga terdapat stratifikasi horizontal, yakni interaksi dengan sesama individu dan alam.

Sebagaimana firman Allah SWT dalam Al Qur'an : (Wama arsalnakaa illa rahmatal lil 'aalamin). "Tidak kami utus kamu (Muhammad) kecuali untuk rahmat kepada seluruh alam.'(QS. Al Ambiya' 107). Islam mengajarkan mengenai interaksi antar umat beragama, memberi tempat kepada umat beragama lain untuk mengamalkan agama dan meyakini sesuai dengan keyakinannya, sesuai dengan firman Allah SWT dalam Al Qur'an (Lakum Dinukum Waliyadiin) (QS. Al Kafirun 6) Artinya : "Bagimu agamamu dan bagiku agamaku." Islam mengajarkan tentang deferensi sosial, sebagaimana dalam Al Qur'an dijelaskan : (Yarfa'illahul ladziina aamanu minkum walladziina uutul 'ilma darojaat). Artinya: "Allah akan mengangkat derajat seseorang yang beriman dan berilmu dari kamu dengan beberapa derajat.” (QS. Mujadilah 13).

Selanjutnya didalam masyarakat Islam adanya perspektif masyarakat Mutamaddin atau civil society, ${ }^{7}$ adalah masyarakat yang memiliki karakteristik mandiri, beretika, memiliki rasa tanggung jawab yang tinggi, berprestasi, egaliter dan cerdas. ${ }^{8}$ Masyarakat ini disebut juga masyarakat kamaliyah, artinya bahwa interaksi dan integrasi masyarakat terwujud. Di mana hal ini terbagi dua yaitu 1). Jamaliyah (interaksi antar kelompok). 2). Jalaliyah (interaksi antar elit).

Pada dasarnya, masyarakat madani dengan kualifikasi kamaliyah yakni masyarakat yang cerdas, egaliter terbuka, etis dan bertanggung jawab, hanya tercipta manakala terjadi perpaduan dialektis antara kelompok Jamaliyah, ${ }^{9}$ kelompok masyarakat mayoritas yang umumnya diam dengan kelompok Jalaliyah, yakni kelompok minoritas dalam masyarakat, tetapi merekalah pengendali jalannya sejarah. Kelompok Jalaliyah adalah mereka yang dalam bahasa sehari-hari disebut seabagai kelompok elit: elit ekonomi, elit intelektual, elit agama, elit kekuasaan dan sebagainya. Masyarakat madani dengan kualifikasi kamaliyah diatas, hanya tercipta manakala terjadi interaksi dan integrasi yang positif antara kelompok jalaliyah dan kelompok jamaliyah.

\footnotetext{
${ }^{7}$ Ali Maschan Moesa, Nasionalisme Kiai: Konstruksi Sosial Berbasis Agama, Cet. 1 (Surabaya : Yogyakarta: IAIN Sunan Ampel Press ; LKiS : Distribusi, LKiS Pelangi Aksara, 2007), 259.

${ }^{8}$ Farid Wajdi Ibrahim, "Pembentukan Masyarakat Madani Di Indonesia Melalui Civic Education," Jurnal Ilmiah Didaktika 13, no. 1 (August 1, 2012), https://doi.org/10.22373/jid.v13i1.469.

${ }^{9}$ M Dawam Raharjo, “Demokrasi, Agama Dan Masyarakat Madani,” Jurnal Fakultas Hukum UII, no. 39 (1999): 25-33. 
Pada masyarakat Tanon, ciri-ciri ini sebagian sudah terlaksana dan sebagian lain belum karena masyarakat Tanon adalah tipe masyarakat agraris dan paternalistik. Keberadaan elit agama Islam sebagai panutan, kuat pengaruhnya terhadap setiap kegiatan keagamaan umat Islam di desa Tanon, merupakan perpaduan dari Islam dan budaya Jawa, sehingga terjadi apa yang diistilahkan dengan Islam Jawa, ${ }^{10}$ ada beberapa amalan yang terjadi hanya khusus pada umat Islam di Jawa. Kondisi ini membawa pengaruh yang positif terhadap keberlangsungan kerukunan masyarakat plural agama di desa Tanon, dan inilah yang ada pada mayoritas realitas yang ada pada mayoritas umat Islam di desa Tanon.

Di dalam sejarah masuknya agama Hindu di jawa umumnya lebih pada proses perpaduan keyakinan tentang adanya dewa-dewa Hindu, dan keyakinan animisme dinamisme yang masih kuat, yang dianut oleh masyarakat jawa, yang mayoritas masih memegang teguh adat istiadat lokal. Kemudian penyerapan keyakinan keagamaan tentang teologi Hindu, lebih mudah difahami dalam konteks cerita-cerita, dongeng-dongeng dan simbol-simbol, upacara-upacara, sebagaimana telah difahami oleh masyarakat jawa, tentang pelaksanaan ritual-ritual dan upacara-upacara, untuk menunjukkan ketaatan kepada Pengeran (istilah Jawa menyebut Tuhan dengan sebutan Pangeran atau "Pengeran").

Masyarakat Tanon yang beragama Hindu, dalam pemahaman keagamaannya lebih memelihara tradisi leluhur, yang secara ritual tradisi itu memang sudah ada sebelum agama lain masuk dan menyatu dengan agama Hindu. Sebagaimana yang diungkapkan oleh bapak Suwiryo, salah satu penerus tokoh agama Hindu, menurut beliau : "miturut dawuh ingkang kula tampi saking para pinisepuh agami Hindu, wonten Tanon mriki, adat istiadat ingkang sampun manunggal lahir batin meniko, sampun wonten sakderengipun agami Hindu mlebet dateng Tanon mriki. Agami Hindu dateng Tanon mboten menganut kasta-kasta kados ingkang wonten pulau Bali, amargi masyarakat Tanon mriki mboten mbentenaken perkawis derajat lan pangkat, sedoyo titah meniko sami kemawon. "(menurut cerita yang berasal dari para tokoh agama hindu yang saya terima, di desa Tanon ini, adat istiadat yang sudah menyatu lahir dan batin itu, sudah ada sebelum agama Hindu masuk di Tanon ini. Agama Hindu di Tanon ini. Agama Hindu di Tanon tidak menganut kasta-kasta seperti yang ada di pulau Bali, karena masyarakat Tanon ini tidak mengenal perbedaan derajat dan pangkat, semua manusia dianggap sama).

10 Ummi Sumbulah, “Islam Jawa Dan Akulturasi Budaya: Karakteristik, Variasi Dan Ketaatan Ekspresif," El-HARAKAH (TERAKREDITASI), December 1, 2012, https://doi.org/10.18860/el.v0i0.2191. 
Dari penjelasan diatas, masyarakat Tanon yang memeluk agama Hindu, meyakini bahwa tidak ada manusia yang mampu hidup sendiri tanpa bantuan orang lain. Kemudian untuk menjaga ketentraman dan keamanan, menurut masyarakat Hindu di desa Tanon, menerapkan prinsip-prinsip toleransi yang ditanamkan oleh para elit agama, pada setiap perkataan yang diucapkan dalam ajarannya (istilah jawa “wejangan"). Sehingga keberadaan agama Hindu, sangat berpengaruh dalam memelihara dan menciptakan keharmonisan masyarakat, melalui kegiatan-kegiatannya yang secara interaktif dan simbolis, selalu melibatkan seluruh komponan lapisan masyarakat dengan upacaraupacara adat yang selama ini dilakukan masyarakat.

\section{Interaksi Sosial dalam perspektif Penganut Agama Katolik}

Agama Katolik awalnya difahami oleh masyarakat Tanon sebagai agama peninggalan kolonial Belanda, persepsi masyarakat ini berlangsung cukup lama, sampai akhirnya ada misi dari pendeta Katolik Kediri, untuk mencoba memahamkan agama Katolik pada masyarakat, dengan dikemas dalam bentuk drama, yang menceritakan tentang Yesus, sebagai juru selamat.

Upaya melalui pertunjukan teatrikal ini, pada awalnya tidak mendapat tanggapan dari masyarakat Tanon. Dalam perkembangan berikutnya, berawal dari satu keluarga yang berkembang ke masyarakat, secara kebetulan keluarga yang masuk agama Katolik itu, merupakan salah seorang tokoh di desa Tanon, yaitu keluarga Mbah Carik. Melalui keluarga Mbah Carik ini, agama Katolik mampu bergerak dinamis melakukan interaksi dengan seluruh komponan masyarakat, dengan tetap mempertahankan adat istiadat masyarakat setempat.

Seperti yang diungkapkan oleh bapak Juki, salah seorang tokoh Agama Katolik. "Senaoso keluarga kulo saking Mbah Carik nganut agama Katolik, nanging nggih taksih mawon ngugemi adat istiadat ingkang sampun kiat, dateng desa Tanon mriki, perkawiisipun mekaten bu, dipun napak-napakaken kulo niki lak tiyang Jowo, dados kados unen-unen ingkang lumprah, ojo nganti ninggal Jawane"(walaupun keluarga saya dari Mbah Carik menganut agama Katolik, tetapi masih tetap memegang teguh adat istiadat yang sudah ada dan kuat didesa Tanon. Masalahnya begini lho bu, bagaimanapun juga saya kan orang Jawa, sebagaimana ungkapan-ungkapan yang mengatakan, jangan sampai meninggalkan budaya Jawa).

Lebih lanjut pak Juki menceritakan tentang ritual adat yang dilaksanakan dalam keluarganya. "Perkawis tetaan utawi selaman caranipun Islam, damel lare jaler, ingkang 
sampun wancinipun balig, dipun tugel pucuk pipisipun, maknane damel kesucian, dateng kulo nggih kulo laksanaaken, nanging nggih benten caranipun bu, slametan nggih enten sakderenge dipun tetak, amargi kulo nganut agami Khatolik, acara meniko nggih sidem, ingkang ngertos namung setunggal keluarga kemawo, dateng tanon mriki perkawis tetaan meniko sampun dados adat istiadat, menawi mboten kulo laksanaaken lare-lare rumaos isin, terosipun. “(tentang “sunatan”atau”selaman” untuk cara Islam, yaitu bagi anak laki-laki yang sudah baligh, dipotong ujung kemaluannya, maknanya sebagai bentuk kesucian, di keluarga saya juga kami laksanakan, tetapi beda caranya bu, slametan ada sebelum anak disunat, karena saya beragama Katholik, acaranya juga diam-diam saja, yang tahu hanya satu keluarga, tentang sunatan sudah menjadi adat istiadat, kalau tidak saya lakukan, anak-anak itu yang merasa malu).

Dari penjelasan diatas, persepsi tokoh agama Katolik, meskipun sudah banyak keluarga yang masuk agama Katolik, mereka tetap memelihara adat istiadat yang ada di desa Tanon. Hal ini menunjukkan adanya interaksi sosial yang positif, antara masyarakat pemeluk agama Katolik dengan lingkungannya.

\section{Interaksi Sosial dalam Perspektif Agama Kristen}

Sebagaimana masuknya agama Katolik, agama Kristen awalnya juga dipandang sebagai agama peninggalan kolonial Belanda. Masyarakat Tanon melihat agama Kristen sebagai sesuatu yang mengkhawatirkan, karena tradisi agama-agama masyarakat Tanon. Masuknya agama Kristen, awalnya membawa persepsi yang negative, namun setelah bapak bapak Soedarto, salah seorang tokoh masyarakat yang kemudian masuk agama Kristen, dan yang dianut adalah aliran Kristen Jawi Wetan, berubah menjadi persepsi yang posisitf. Pemahaman ajaranajaran Kristen Jawi Wetan ini, adalah ajaran tentang kasih sayang pada sesama manusia, dan mengedepankan unsur-unsur kemanusiaan yang tetap mempertahankan adat istiadat Jawa.

Sebagaimana yang diungkapkan bapak Soedarto. "Rumiyen kulo niki inggih Islam bu, nanging kados liyane niku, mboten patos ngertos babagan agami Islam sakleresipun, pas kulo panggeh pak Sastro, ingkang sakderenge kulo nggih mboten ngerti menawi piyambake niku nganut agami Kristen, amargi serawung kulo raket sanget kalian pak Sastro, akhiripun kulo sekedik-kedik mangertosi babagan agami Kristen, ingkang dianut pak Sastro, lajeng kulo nggih mangertos lan luwih mantep, amargi agami Kristen ingkang dipun anut pak Sastro niku aliran Kristen Jawi Wetan, ingkang wonten ajaranipun tasih ngugemi babagan budaya adat Jawi." (dulu saya ini juga beragama 
Islam bu, tetapi seperti lainnya, tidak begitu memahami agama Islam dengan benar, pada saat saya bertemu pak Sastro, yang sebelumnya saya juga tidak tahu kalau dia menganut agama Kristen, karena pergaulan saya sangat dekat dengan pak Sastro, akhirnya saya sedikit demi sedikit, mengerti dan memahami tentang agama Kristen yang dianut oleh pak Sastro, kemudian saya mengerti dan lebih mantap memehami lagi, karena agama Kristen Jawi Wetan, yang dalam ajarannya masih kuat dengan budaya adat Jawa).

Kemudian langkah bapak Soedarto mendapat tanggapan positif dari beberapa keluarga di desa Tanon, yang selanjutnya menganut agama Kristen Jawi Wetan, berdasarkan kondisi diatas, masyarakat Kristen di desa Tanon yang memegang teguh ajaran cinta-kasih, dan mengedepankan kegiatan kemanusiaan, menimbulkan interaksi yang positif di sebagian komponen masyarakat desa Tanon.

Dari penjelasan tentang interaksi sosial dalam perspektif agama Katolik di desa Tanon dapat diperoleh temuan bahwa elit agama Kristen dalam melaksanakan kegiatan keagamaannya lebih membaur pada aspek adat istiadat Jawa.

\section{Tipologi Masyarakat Tanon}

Sebagaimana dijelaskan oleh bapak Suryo Widodo, selaku tokoh yang dituakan di desa Tanon, ketika penulis menanyakan tentang kondisi sebenarnya dari warga desa, beliau menjelaskan sebagai berikut:

"Mekaten bu,wonten desa Tanon mriki, sejatose sedoyo wargo desa nggih sampun nganut agami, amargi kiblating manungso niku kan sedoyo dateng gusti Allah, nanging diwangsulaken malih dateng pemanggihe piyambakpiyambak, tujuanipun sedoyo kolo wau sami dateng arah kesaenan. Kesaenan nggih lumambar dateng warga sami, lan dateng gusti Allah kang murbeng dumadi" (Begini bu, di desa Tanon ini , sebenarnya semua warga desa sudah menganut agama, sebab kiblat manusia itu semua ke Allah SWT, tetapi tetap dikembalikan ke diri mereka sendiri-sendiri, tujuannya semua sama menuju satu arah yaitu kebaikan. Kebaikan itu juga ditujukan ke masyarakat dan kepada Allah SWT).

Setelah itu penulis menanyakan kembali, bagaimana tentang adat istiadat yang berkembang di desa Tanon, yang kaitannya dengan kerukunan umat beragama. Bapak Suryo Widodo menjelaskan kembali:

"Perkawis adat istiadat ingkang wonten desa Tanon, lan sakmangke dipun ugemi kalian sedoyo warga deso, meniko sejatosipun sampun dipun uri-uri wiwit mbah-mbah buyut rumiyin ngantos sakmeniko, ingkang kajibah nguri-uri inggih sedoyo warga deso, lumantar dawuh-dawuh ingkang dipun paringaken dateng anak putu arupi perintah kalian larangan. Bilih perintah kalian larangan ingkang dipun wucalaken meniko, miturut keyakinan agamanipun 
piyambak-piyambak, lan pitutur-pitutur ingkang dipun pendet saking gebyaring kahanan donyo saisine saking laku lan tirakatipun poro sesepuh".

Adat istiadat di desa Tanon dan yang sekarang masih diyakini dan dilestarikan telah lama dilaksanakan oleh pendahulu masyarakat desa Tanon sampai sekarang, dengan perantara dari nasehat-nasehat dan pelajaran ke anak cucu berupa perintah dan larangan. Dari perintah dan larangan yang diajarkan itu diambil dari keyakinan agama masingmasing dan nasehat yang berasal dari pengetahuan alam semesta, yang dilakukan dengan puasa dan berjaga (tirakat) dari para orang tua terdahulu).

"Manungso meniko dasare tansah kirang lan mboten wonten mareme. Niku sampun dados wataking manungso ingkang urip dateng alam donyo. Lajeng sedoyo tansah ngupoyo amprih kekarepanipun saged kaleksanan, nanging ingkang ngupadi dateng donyo mboten setitik nanging katah, ugi mbeto watak piyambak-piyambak. Sarehne sedoyo meniko gadah pemanggih ingkang benten-benten, asring podo rebut bener dewe-dewe. Dateng desa Tanon mriki kahananipun nggih kados mekaten. Nanging sedoyo kolo wau sadged dipun manunggalaken kanthi dasar keyakinan agami ingkang dipun anut. Lajeng damel luwesing sesrawungan para wargo amprih mboten wonten tukar padu, para wargo ingkang sampun gadah adat istiadat budaya lan nyawiji lahir tumusing batin, dipun ginaaken wonten kehidupanipun saben dinten. “"

Manusia itu pada dasarnya selalu merasa kurang dan tidak puas atas apa yang dimilikinya. Di desa Tanon ini kondisinya juga demikian secara umum. Tetapi semua itu semua bisa disatukan dengan dasar keyakinan agamanya masing-masing. Kemudian untuk mencairkan suasana pergaulan biar luwes dan baik, warga desa yang sudah punya adat istiadat budaya, mengunakannya dalam kehidupan sehari-hari).

"Dateng Tanon ngriki masyarakat ingkang nganut agama Islam, Hindu, Kristen, Katolik niku saged nyawiji lan rukun, amargi saking adat istiadat budaya, Slametan tingkepan bayi, pitonan bayi, slametan tiyang tinggal donyo, pitung dinanan, patang puluhan, satusan, sewunan, ugi slametan bade ngedekaken griyo, slametan wiwit tanam dateng sabin bancaan perkawinan, sedoyo umat agami nggih ngelaksanaaken acara-acara niku, tapi dongane ingkang benten miturut agaminipun piyambak-piyambak saged dipun tinggalaken. Terosipun mereka wedi kuwalat "

Di desa Tanon ini masyarakat yang menganut agama Islam, Kristen, Hindu dan Katolik itu bisa menjadi satu dan rukun, karena dari adat istiadat dan budaya, slametan dan tingkepan bayi, tujuh bulanan bayi, slametan orang meninggal dunia, slametan tujuh hari kematian, slametan empat puluh hari, slametan seratus hari, slametan seribu hari, juga slametan akan mendirikan rumah, slametan akan memulai masa tanam di sawah, syukuran perkawinan, semua umat agama dan kepercayaannya masing-masing. Acaraacara seperti ini sudah menjadi adat istiadat setiap hari, dan tidak bisa ditinggalkan, hal 
ini dikarenakan masyarakat desa Tanon mempercayai bahwa jika meninggalkan tradisi ini akan menimbulkan kuwalat (kepercayaan akan bernasib sial karena meninggalkan adat dan tradisi)

'Menawi dinten riyoyo-riyoyo agami, dateng Tanon mriki sedoyo sami gentosan silaturahmi lan mengucapkan selamat, contone menawi pas dinten riyoyo Islam nggih sedoyo umat Hindu, Kristen, Katolik sami nyalami lan silaturahim dateng umat Islam ugi ngucapaken sugeng riyadin (Idul Fitri), menawi dinten Natal umat Kristen lan Katolik nggih ngucapaken sugeng Natalan, semanten ugi menawi dinten riyoyo Hindu nggih ngucapaken sugeng Galungan, niku dilakoni kanti ikhlash kalian para sesepuh agami, umatipun nem, sepuh, lare-lare, dados rukun mboten wonten perasaan perbedaan agami babar pisan. Dados menawi digambaraken mekaten, senaoso benten agami lan keyakinanipun, nanging lahir batinipun para wargo Tanon mriki saged celak saking setunggal-setunggalipun tiyang “

Setiap adanya perayaan dari salah satu agama yang ada di desa Tanon, masyarakat Tanon yang berbeda agama selalu memberikan ucapan selamat kepada warga yang merayakannya. Ajaran masing-masing agama yang menjadikan masyarakat terdisintegrasi dikesampingkan oleh masyarakat Desa Tanon. Hal ini karena masyarakat Tanon menganggap bahwa kehidupan dalam masyarakat harus berjalan, sementara agama selain dijadikan sebagai identitas juga dianggap sebagai alat untuk saling berbagi kebaikan, beragama yang baik adalah jika individu memperlakukan sesamannya dengan baik. Hal ini dimanifestasikan dengan tradisi bergantian silaturahmi dan mengucapkan selamat pada hari perayaan agama tertentu. Kebiasaan seperti itu dilakukan dengan ikhlas oleh para elit agama, para umatnya, yang muda dan anak-anak semuanya. Sehingga rukun seperti tidak ada perbedaan agama dan keyakinannya tetapi lahir batin warga Tanon ini dapat dekat diantara satu dengan yang lain.

"Dateng Tanon mriki taksih wonten satunggaling budaya animisme, ingkang dipun yakini sekawan pemeluk agama Islam, Hindu, Kristen, Katolik, wujudipun niku wancine bulan Suro, nanging dateng panggenan wargo dintenipun benten, contone kados dateng masyarakat Tanon prosekawan ngidul niku dinten Kemis Paing. Wanci suro pas dinten Rebo, getok tular bilih "bariane sesuk Kemis Paing” acara selametan barian wonten sasi suro niku sedoyo pemeluk agama nderek acara meniko, wanci sonten sekitar jam sekawan mungelaken kentongan lajeng warga dugi kalian mbeto sedekahan utawi berkat arupi dedaharan warni tiap keluarga. "

Di Tanon ini masih ada salah satu budaya animisme, yang diyakini oleh empat pemeluk agama, Islam, Hindu, Kristen dan Katolik, buktinya pada saat bulan Suro, tetapi di tiap lingkungan masyarakat harinya tidak sama, contohnya di masyarakat Tanon yang berada di perempatan ke selatan harinya Kamis Paing. Pada saat bulan Suro di hari Rabu, 
warga desa sudah mulai mengundang dengan mengatakan "bariannya besuk hari Kamis Paing". Acara slametan barian di bulan suro itu semua pemeluk agama ikut dalam acara itu, sekitar jam empat sore, slaah satu warga membunyikan kentongan, kemudian warga desa datang dengan membawa sedekah atau berkat, yang berupa makanan yang bermacam-macam dari setiap keluarga.

"Dateng acara slametan barian niku mangke wonten sesepuhipun saking agami Hindu naminipun pak Poh ingkang ngujupaken ndamel boso agung inget kulo mekaten "dinten pitu pekenan gangsal ingkang ngaweruhi ingkang mbaurekso dusun Tanon"kinten-kinten ngaten lajeng dipun akhiri kalian doa ndamel acara Islamingkang dongo dateng lingkungan niku biasanipun pak Ahmad Zuhdi, senaoso dateng mriku wonten umat Hindu, Kristen lan Katolik."

Di acara barian itu nanti ada sesepuh yang berasal dari agama Hindu namanya pak Poh yang memulai dan menyajikan acara tersebut dengan menggunakan bahasa agung, inget saya begini "hari ketujuh pasaran kelima, yang mengetahui yang menguasai desa Tanon" kira-kira begitu dan kemudian diakhiri dengan menggunakan doa dengan cara agama Islam, di lingkungan itu biasanya bapak Ahmad Zuhdi, walaupun di acara itu terdapat umat Hindu, Kristen, Katolik.

"Slametan barian sak sampunipun kulo taskehaken lan kulo tangkletaken dateng para sesepuh Tanon mriki. Miturut tiyang sepuh barian niku asalipun saking boso Persi teng Islam mungele "baroa, bariu bariatan ingkang artinipun "nglepas" lha nglepas maksutipun tiyang sepuh niku nglepas saking beboyo lan sambikolo. Niatipun acara slametan barian miturut keyakinan para warga Tanon mriki niku memohon dateng Allah supados desa Tanon niku memohon dateng Allah supados desa Tanon niku aman lan tentrem, lajeng nglaksanaaken ritual keagamaan ingkang dipun wujudaken barian meniko."

Slametan barian itu setelah saya tanyakan dan rujukan kepada para orang tua di Tanon ini, menurut mereka barian itu asalnya dari bahasa Persi, yang dalam tafsiran berbunyi "Baroa yubariu, bariatan yang artinya "melepas" kemudian melepas itu mengandung maksud menurut para orang tua, itu melepas dari semua bahaya dan ancaman. Niat dalam acara slametan barian menurut para warga, adalah memohon kepada Allah supaya desa Tanon itu aman dan tentram, dan melaksanakan prosesi keagamaan yang disebut barian itu.

Dengan gambaran kondisi interaksi sosial agama tersebut diatas, nampak ada pemahaman yang sama tentang kehidupan bersama, yang didasarkan atas saling toleransi beragama, dan sekaligus interaksi budaya, oleh semua lapisan masyarakat di desa Tanon. Adapun lapisan masyarakat di desa Tanon, berdasarkan tingkat pemahaman keagamaan, dapat terbagi menjadi tiga kelompok. Yang pertama adalah kelompok elit agama, yang 
dalam hal ini terdiri dari para tokoh-tokoh agama setempat, yang menjadi panutan dan pengambil keputusan dalam pelaksanaan kehidupan di masing-masing agama, dan sebagai pemegang fatwa terhadap pemeluknya masing-masing. Kedua, kelompok menengah yang fungsinya sebagai pelaksana setiap kegiatan keagamaan di masingmasing agama dan juga sebagai wakil dari masing-masing agama, dalam rangka menciptakan keharmonisan hubungan keagamaan di desa Tanon, kelompok ini terdiri dari para kaum muda dari masing-masing agama, yang secara nyata terlibat langsung dalam setiap kepanitiaan acara-acara keagamaan. Ketiga, adalah kelompok abangan yaitu para penganut agama yang secara langsung taat dan patuh kepada elit agama masingmasing, yang terkait dengan perintah dan larangan agama masing-masing. Penjelasan diatas dapat digambarkan seperti gambar di bawah ini:

Gambar 3

Pembagian Masyarakat Desa Tanon

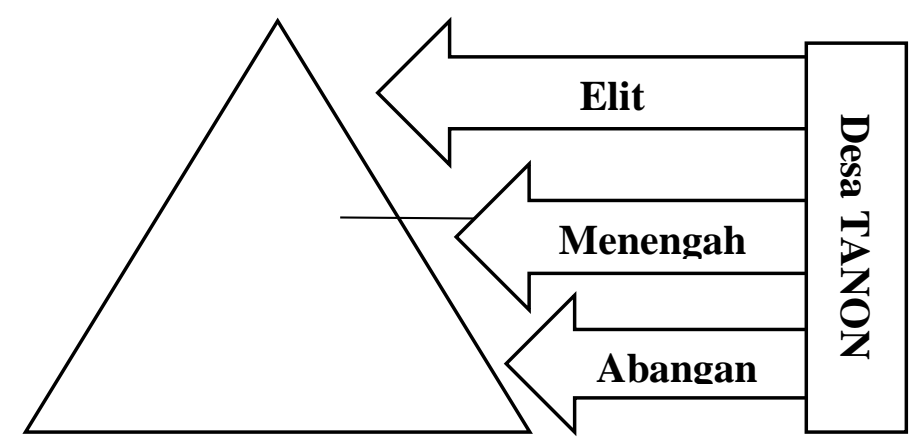

Selanjutnya dalam kenyataan sehari-hari, keberadaan kehidupan keagamaan secara kwantitatif, membentuk watak solidaritas lokal, yang berfungsi untuk membentengi diri dari pengaruh negatif. Kondisi ini menciptakan keharmonisan kehidupan umat beragama di desa Tanon, yang berpijak pada keyakinan agama masingmasing dan budaya masyarakat setempat. Adapun gambaran masyarakat desa Tanon dalam keberagaman agama secara kuantitatif dapat dijelaskan sebagaimana grafik dibawah ini:

\section{Grafik 1}

Umat Beragama dalam Stratifikasi Keberagaman

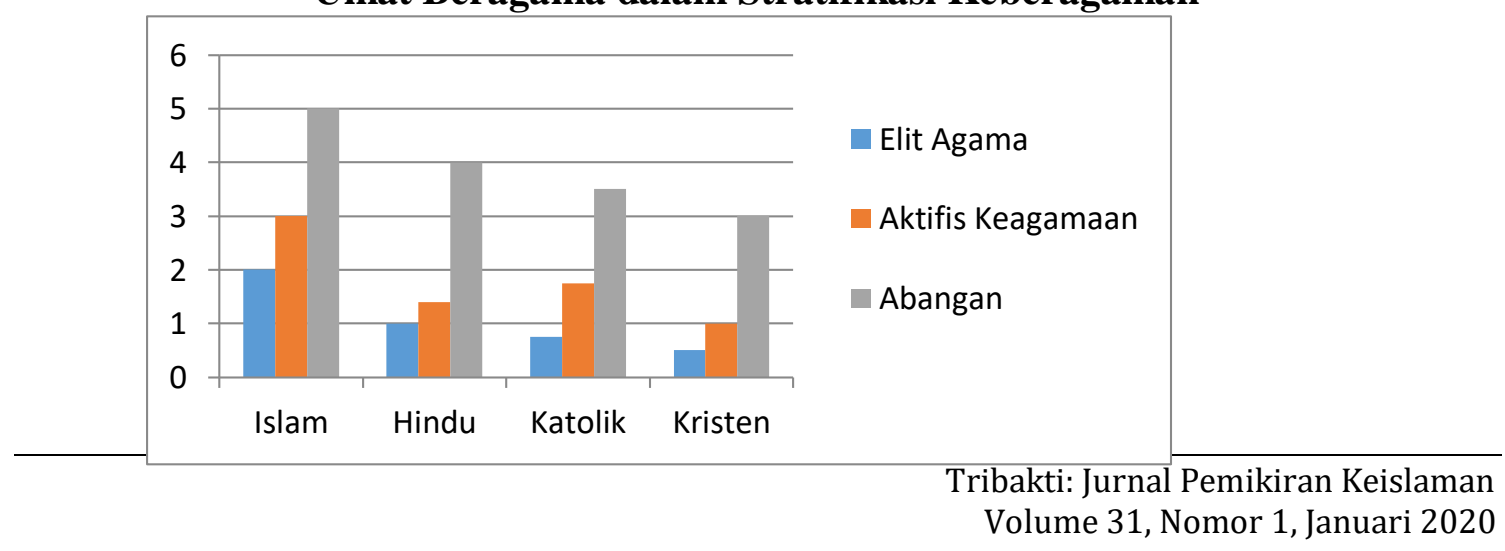


Dari grafik tersebut dapat dijelaskan, bahwa prosentase terbesar adalah pada masyarakat abangan di masing-masing agama dan kelompok, ini adalah kelompok yang paling besar jumlahnya, dalam melaksanakan perkawinan campuran, atau yang dalam bahasa lokal disebut perkawinan pelangi. Keberagaman agama di desa Tanon, berinteraksi dengan budaya setempat, bahkan terjadi integrasi budaya yang terkait dengan ritual-ritual budaya yang rutin dilaksanakan di desa Tanon.

Terdapat empat pemeluk agama di desa Tanon, yaitu Islam, Hindu, Katolik dan Kristen, semua agama tersebut adalah agama samawi artinya berasal dari Tuhan dan dibawa oleh Nabi, sedangkan untuk Hindu berasal dari budaya. Semua sama-sama menyanjung nilai-nilai kemanusiaan, jadi bersifat universal. Inilah teologi yang mempersatukan umat beragama di desa Tanon. Dalam memahami agama masing-masing, menggunakan standar ganda, yang pertama subyektif, artinya bahwa keyakinan kebenaran agamanya absolut dan mutlak, sedangkan yang kedua, tidak subyektif artinya bahwa, agama lain juga tidak salah. Hal ini diistilahkan dengan teologi Religonum, yakni memaksimalkan teologinya kepada teologi umat beragama yang lain. ${ }^{11}$ Adapun gambaran interaksi agama-agama dengan budaya lokal, adalah sebagaimana dalam gambar dibawah ini:

Gambar 4

Interaksi agama dengan budaya lokal

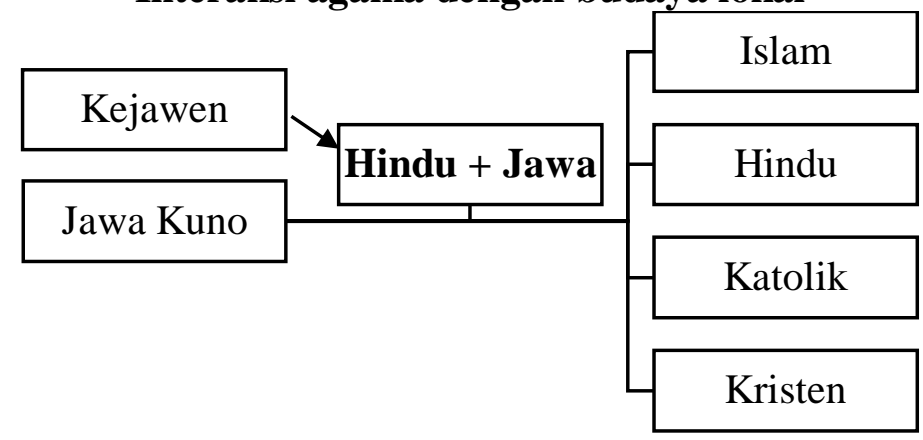

Keyakinan umat beragama di Tanon, mula-mula adalah menganut budaya kuno yang dinamakan kejawen. Perpaduan Hindu dan Jawa, kemudian dalam perkembangannya menganut agama Islam, Katolik, Hindu, dan Kristen tetapi masih mengamalkan budaya kejawen dan keyakinan agama masing-masing, karena keadaan persamaan budaya yang berintegrasi dengan agama-agama ini, maka masing-masing ymat beragama, tidak saling membenarkan agamanya yang paling benar. Masyarakat

11 Fredi Siagian, “Rekonstruksi Misi Gereja Di Abad 21," Syntax Literate; Jurnal Ilmiah Indonesia 1, no. 4 (2016), http://www.jurnal.syntaxliterate.co.id/index.php/syntax-literate/article/view/31.

Tribakti: Jurnal Pemikiran Keislaman

Volume 31, Nomor 1, Januari 2020 
abangan yang terdapat di semua agama memiliki toleransi dan interaksi yang tinggi terhadap budaya lokal.

Interaksi dengan budaya lokal, semua agama menunjukkan positif, praktek ibadah atau ritual, sebagian bersinggungan dengan budaya lokal, yang dipadukan dengan keyakinan masing-masing agama. Inilah sebagai simbol keharmonisan umat beragama di Tanon yang plural agama. Di bawah tabel alur interaksi agama dan budaya lokal:

Tabel 12

Alur Interaksi Agama dan Budaya Lokal

\begin{tabular}{|l|c|c|c|c|}
\hline \multirow{2}{*}{ Interaksi } & \multicolumn{4}{|c|}{ Agama-agama } \\
\cline { 2 - 5 } & Islam & Hindu & Katrolik & Kristen \\
\hline Budaya Lokal & + & + & + & + \\
\hline
\end{tabular}

Keterangan Tabel :
a. Interaksi Hindu dengan budaya lokal
$=+:+\quad$ (ada dan baik)
b. Interaksi Islam dengan budaya lokal
$=+: \quad$ (ada dan baik)
c. Interaksi Kristendengan budaya lokal
$=+:+\quad($ ada dan baik $)$
d. Interaksi Katolik dengan budaya lokal
$=+: \quad$ (ada dan baik)

Semua agama berinteraksi baik dengan budaya lokal, yang menghasilkan positif, praktek ibadah atau ritual yang lain, sebagian bersinggungan dengan budaya lokal yang dipadukan dengan keyakinan masing-masing agama.

Di bawah ini dijelaskan, tentang keterkaitan antara agama dan budaya slametan, sebagai simbolitas kerukunan dan keharmonisan masyarakat Tanon.

\section{Gambbar 5}

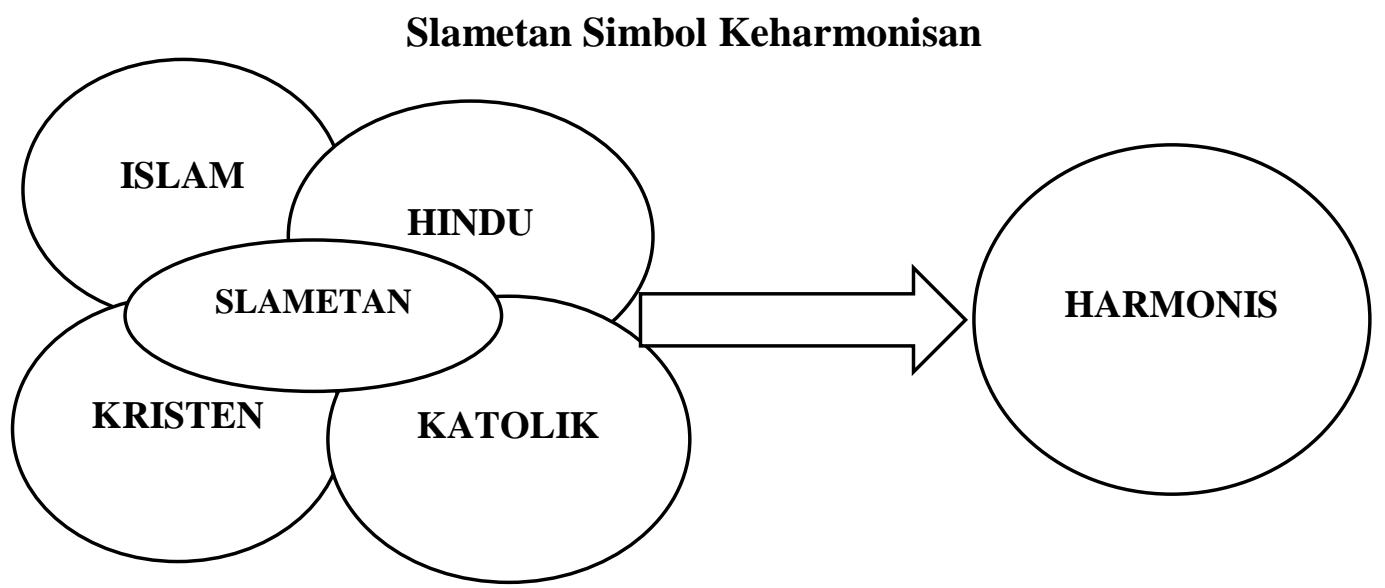

Keterangan Gambar :

Ritual slametan ada di semua agama, Islam, Hindu, Katolik dan Kristen, ini adalah bukti salah satu simbol keharmonisan, bahwa mereka sama-sama memiliki keyakinan 
yang sama, bukan beda, sehingga agama yang berbeda bukan merupakan sekat atau jarak sosial bagi umat beragama di desa Tanon, dan masih banyak ritual lain, yang menjadi keyakinan umat beragama di Tanon.

Umat beragama di desa Tanon memiliki lokal genius, yakni memiliki agama, akan tetapi masih ada kepercayaan yang diyakini dan memiliki pengaruh di masyarakat. Selain hal tersebut, juga percaya bahwa benda-bendamempunyai kekuatan gaib. Perpaduan antara animisme, mistik dan agama, mistik dan agama disebut senkritisme. Kegiatan semacam ini terlihat pada acara: slametan, kelahiran, khitanan, pernikahan, kematian, mendirikan rumah, mulai menanam padi, panen padi, kepercayaan kepada hitungan hari Pon, Kliwon, Wage, Legi, Pahing dan sebagainya.

Para elit agama di desa Tanon mengutamakan keharmonisan, dalam aspek yang berhubungan antar umat beragama, dalam bentuk kebersamaan dan gotong-royong, dalam kehidupan sehari-hari. Keharmonisan yang terjadi selama ini di desa Tanon, telah dijaga dan dilestarikan oleh para elit agama, meskipun dengan mengorbankan hak-hak individu.

Sebagaimana sudah menjadi wacana yang sangat familiar dalam dunia akademik, Geertz menulis sebuah buku yang amat menggemparkan jagat akademik Indonesia: The Religion of Java. Dalam buku yang diterjemahkan dalam bahasa Indonesia menjadi agama masyarakat Jawa ini, memaparkan tipologi atau kategori agama masyarakat Jawa, melalui tiga varian yang disebutnya: Abangan, Santri dan Priyayi. Menurut Gerrtz, tiga varian keberagaman masyarakat Jawa diambil dari istilah yang digunakan oleh orang Jawa sendiri, ketika mendefinisikan kategori keagamaan mereka. Deskripsi singkat dari tiap-tiap tipologi keagamaan tadi, dapat dikemukakan demikian. Pertama, Abangan, Istilah ini didefinisikan oleh Gerrtz sebagai teologi dan ideologi orang Jawa ${ }^{12}$ yang memadukan atau mengintegrasikan unsur-unsur animistik, Hindu, dan Islam.

Pengejawantahan dari kelompok sosial abangan ini dapat dilihat dalam berbagai kepercayaan masyarakat Jawa, terhadap berbagai jenis makhluk halus, seperti memedi (suatu istilah untuk makhluk halus seacara umum), tuyul (makhluk halus yang menyerupai anak-anak, tapi bukan manusia), banaspati (makhluk halus yang menyerupai api), lelembut (makhluk halus yang mempunyai sifat kebalikan kebalikan dari memedi, yaitu masuk dalam tubuh manusia dan menyebabkan seseorang jatuh sakit atau gila), dan sebagainya,

\footnotetext{
${ }^{12}$ Geertz, The Religion of Java. 
Kalangan abangan juga sangat rajin dalam mengadakan berbagai upacara slametan, seperti:
a Slametan kelahiran
d Slametan kematian
b Slametan khitanan
e Slametan desa
c Slametan perkawinan
f Slametan Suro

Kedua, Santri, Gerrtz mendefinisikan santri sebagai orang Islam yang taat pada ajaran-ajaran atau doktrin agama, dan menjalankannya secara taat berdasarkan tuntunan yang diberikan agama. Dengan definisi itu, agaknya kata lain yang lebih cocok untuk menyubstitusi istilah santri, adalah Muslim sejati. Berbeda dengan kalangan abangan yang cenderung abai terhadap berbagai ritual Islam, kalangan santri ini justru sangat patuh terhadap doktrin Islam dan ritual, dengan titik kuat pada keyakinan dan keimanan.

Ketiga, Priyayi. Gerrtz mendefinisikan priyayi sebagai kelompok orang yang mempunyai garis keturunan bangsawan atau darah biru, yakni mereka yang mempunyai kaitan langsung dengan raja-raja Jawa dahulu. Tampaknya, varian ini mengalami pemekaran makna yang cukup signifikan. Saat ini, mereka yang mempunyai status sosial yang cukup tinggi, baik karena banyak harta atau mempunyai jabatan tertentu, dapat dikategorikan sebagai kalangan priyayi modern.

Pengejawantahan dari kelompok sosial priyayi ini dapat dilihat dalam berbagai etiket, seni dan praktik mistik. Etika dikalangan priyayi menyangkut bahasa lisan dan bahasa sikap. Bahasa lisan terlihat dari tingkatan bahasa yang dipakai dalam percakapan sehari-hari. Sementara itu, aspek seni dan kepercayaan priyayi dinyatakan dalam berbagai manifestasi, seperti yang dinyatakan dalam bentuk tembang atau disebut juga dengan istilah wirama. Adapun aspek mistik merupakan kelanjutan dari aspek seni tadi. Tujuan yang hendak dicapai dengan adanya praktik mistik ini adalah mencapai kejernihan pengetahuan yang dalam.

Akhirnya, Gerrtz sampai pada muara kesimpulan, bahwa yang dinamakan agama Jawa tidak lain adalah sinkretisme. Ia melihat adanya perpaduan antara keprcayaan asli masyarakat Jawa dan kepercayaan Islam yang datang belakangan. Hal ini dapat dilihat, misalnya, dalam praktik slametan terkandung berbagai unsur adat lokal dan Islam. Disitu ada praktik magis berupa kepercayaan kepada roh, dan ada pula penyisipan unsur Islam, yaitu doa. 


\section{Kesimpulan}

Berdasarkan pemaparan di atas, dapat disimpulkan beberapa kesimpulan sebagai berikut; pertama, Elit agama Islam, Hindu, Katolik dan Kristen di desa Tanon sebagai figur panutan masyarakat berperan sebagai penyeimbang anatara kehidupan keagamaan dan adat istiadat budaya setempat. Kedua, Agama Hindu di desa Tanon tidak mengenal kasta, elit agama Hindu melaksanakan ajarannya disesuaikan dengan adat istiadat budaya masyarakat, dalam kehidupan sehari-hari. Ketiga, Elit agama Katolik dalam melaksanakan kehidupan agama, lebih mengedepankan pada keutuhan internal umat, dan bersikap lebih toleran terhadap agama-agama lain, dengan terlibat pada kegiatan-kegiatan lintas agama, seperti pada acara slametan atau bersih desa. Keempat, Elit agama Kristen dalam melaksanakan kegiatan keagamaannya lebih membaur pada aspek adat istiadat Jawa. Kelima, Elit-elit agama masih memegang teguh adat-istiadat dan budaya masyarakat setempat, dengan masih melaksanakan ritual slametan. Keenam, Masyarakat agama desa Tanon terbagi menjadi 3 bagian yaitu : elit agama, menengah (aktifis keagamaan), Awam (masayarakat abangan). Dan ketujuh, Keberadaan keberagaman agama yang ada, menjadi bentuk komunikasi budaya dan perkembangannya, sampai sekarang, masyarakat masih tetap memegang teguh adat istiadat dan simbo-simbol budaya setempat.

\section{Daftar Pustaka}

Ahimsa-Putra, Heddy Shri. "Fenomenologi Agama: Pendekatan Fenomenologi Untuk Memahami Agama.” Walisongo: Jurnal Penelitian Sosial Keagamaan 20, no. 2 (December 2012): 271-304. https://doi.org/10.21580/ws.20.2.200.

Fidiyani, Rini. "Kerukunan Umat Beragama Di Indonesia (Belajar Keharomonisan Dan Toleransi Umat Beragama Di Desa Cikakak, Kec. Wangon, Kab. Banyumas).” Jurnal Dinamika Hukum 13, no. 3 (September 2013): 468-482. https://doi.org/10.20884/1.jdh.2013.13.3.256.

Geertz, Clifford. The Religion of Java. Nachdr. Anthropology/Comparative Religions. Chicago: Univ. of Chicago Press, 1996.

Kholil, A. "Agama Dan Ritual Slametan: Deskripsi-Antropologis Keberagamaan Masyarakat Jawa.” El-HARAKAH (TERAKREDITASI) 1, no. 1 (April 30, 2009). https://doi.org/10.18860/el.v1i1.424.

Magister Arsitektur Lingkungan Binaan, Universitas Brawijaya, Mike Yuanita, Antariksa Antariksa, Jurusan Arsitektur, Fakultas Teknik, Universitas Brawijaya, Lisa Dwi Wulandari, and Jurusan Arsitektur, Fakultas Teknik, Universitas Brawijaya. "Ruang Budaya Pada Proses Daur Hidup (Kelahiran) Di Dusun Wedoro Gresik." 
Review of Urbanism and Architectural Studies 13, no. 1 (June 1, 2015): 26-35. https://doi.org/10.21776/ub.ruas.2015.013.01.3.

Moesa, Ali Maschan. Nasionalisme Kiai: Konstruksi Sosial Berbasis Agama. Cet. 1. Surabaya: Yogyakarta: IAIN Sunan Ampel Press ; LKiS : Distribusi, LKiS Pelangi Aksara, 2007.

Nazmudin, Nazmudin. "Kerukunan Dan Toleransi Antar Umat Beragama Dalam Membangun Keutuhan Negara Kesatuan Republik Indonesia (NKRI).” Journal of Government and Civil Society 1, no. 1 (February 22, 2018): 23. https://doi.org/10.31000/jgcs.v1i1.268.

Raharjo, M Dawam. "Demokrasi, Agama Dan Masyarakat Madani." Jurnal Fakultas Hukum UII, no. 39 (1999): 25-33.

Siagian, Fredi. "Rekonstruksi Misi Gereja Di Abad 21." Syntax Literate ; Jurnal Ilmiah Indonesia $1, \quad$ no. 4 (2016). http://www.jurnal.syntaxliterate.co.id/index.php/syntax-literate/article/view/31.

Sumbulah, Ummi. "Islam Jawa Dan Akulturasi Budaya: Karakteristik, Variasi Dan Ketaatan Ekspresif." El-HARAKAH (TERAKREDITASI), December 1, 2012. https://doi.org/10.18860/el.v0i0.2191.

Universitas Negeri Jakarta, and Ahmad Hakam. "Communal Feast Slametan: Belief System, Ritual, and the Ideal of Javanese Society." Hayula: Indonesian Journal of Multidisciplinary Islamic Studies 1, no. 1 (January 31, 2017): 97-111. https://doi.org/10.21009/hayula.001.1.06.

Wajdi Ibrahim, Farid. "Pembentukan Masyarakat Madani Di Indonesia Melalui Civic Education." Jurnal Ilmiah Didaktika 13, no. 1 (August 1, 2012). https://doi.org/10.22373/jid.v13i1.469. 